\author{
N. Ucar ${ }^{1 *}$, M. Yigit ${ }^{2}$, A. Calik ${ }^{3}$ \\ ${ }^{1}$ Süleyman Demirel University, Faculty of Arts and Sciences, Department of Physics, Isparta, \\ Turkey \\ ${ }^{2}$ Süleyman Demirel University, Graduate School of Natural and Applied Sciences, Isparta, \\ Turkey \\ ${ }^{3}$ Isparta University of Applied Sciences, Faculty of Technology, Mechanical Engineering, \\ Isparta, Turkey \\ *nazimucar@sdu.edu.tr
}

\title{
METALLURGICAL CHARACTERIZATION AND KINETICS OF BORIDED 34CrNiMo6 STEEL
}

\begin{abstract}
Boriding of 34CrNiMo6 steel was performed in a solid medium consisting of Ekabor-II powders at 1123, 1173 and $1223 \mathrm{~K}$ for 2, 4 and $6 \mathrm{~h}$. Morphological and kinetic examinations of the boride layers were carried out by optical microscopy, scanning electron microscopy (SEM) and X-ray diffraction (XRD). The thicknesses of the boride layers ranged from $22 \pm 2.3$ to $145 \pm 4.1$ depending on boriding temperature and time. The hardness of boride layer was about $1857 \mathrm{HV}_{0.1}$ after boriding for $6 \mathrm{~h}$ at $1223 \mathrm{~K}$, while the hardness of the substrate was only around $238 \mathrm{HV}_{0.1}$. Growth rate constants were found to be between $1.2 \times 10^{-13}-9.8 \times 10^{-13} \mathrm{~m}^{2} / \mathrm{s}$ depending on temperature. The activation energy for boron diffusion was estimated as $239.4 \pm 8.6 \mathrm{~kJ} \mathrm{~mol}^{-1}$. This value was comparable to the activation energies reported for medium carbon steels in the literature.
\end{abstract}

Keywords: Boriding; 34CrNiMo6 steels; boride layer; Ekabor II; growth rate constants; activation energy

\section{INTRODUCTION}

34CrNiMo6 steel is a typical medium-carbon low-alloy steel widely used in the automobile industry for its high strength, good ductility, and excellent corrosion resistance [1-3]. However, its surface properties are often considered inadequate for certain engineering applications requiring high resistance to wear such as ring gears, valve stems, connecting rods, shackle pins, etc. [4,5]. Surface treatments are therefore required to overcome this disadvantage. Boriding (also known as boronizing) is a thermochemical surface hardening process in which boron atoms are diffused into the surface of a workpiece to form single-or multi-phase boride layers with the base metal $[4,6-8]$. The boriding temperature and time, as well as the alloying elements in the material to be borided, affect the formation of boride(s) and thickness of the boride layer formed [4,9]. The formation of a boride layer on the surface of the materials can greatly influence mechanical properties [10,11]. Compared to conventional surface hardening processes, it is possible to obtain more than twice the 
hardness of the substrate at the surface by the boriding process in iron-based materials [12]. Gunes et al. [13] reported that the surface hardness of Ni 201 significantly increases (1642$\left.1854 \mathrm{HV}_{0.05}\right)$ due to the formation of hard boride phases, whereas the hardness of substrate material was on average $185 \mathrm{HV} 0.05$.

To control the boriding process, evaluation of kinetic parameters is essential. Many models have been developed over the years to optimize the thicknesses of boride layers obtained in industrial boriding applications [14-16]. Ortiz-Domínguez et al. [16] and ZunoSilva et al. [17] indicated that boron diffusion was dependent upon the mass balance at the $\mathrm{Fe}_{2} \mathrm{~B}$-substrate interface on ASTM A36 and AISI 1045 steels. Another model was developed by Keddam and Kulka [18] to explain the boriding kinetics of AISI D2 steels. This method is an integral method, which takes into account the effect of boride incubation time of the total boride layer $(\mathrm{FeB}+\mathrm{Fe} 2 \mathrm{~B})$. Another approach, based on the integral method, was proposed by Zuna-Silva et al. [19]. The common result of these three models is that the growth kinetics of boride layer is governed by a parabolic growth law.

In the literature, studies are available on the boride layer growth kinetics of mediumcarbon low-alloy steels such as 34CrAINi7, AISI 1020-1035, AISI 4130 and AISI 4140 [2024]. However, at the time of this paper, there are no studies that describe the boriding properties of 34CrNiMo6 steel in detail. This study aims to therefore investigate whether the boriding process applies to $34 \mathrm{CrNiMo} 6$ steel, and if so, to examine the diffusion kinetics of and microhardness of borided 34CrNiMo6 steels in the 1123-1223 K temperature range for variable exposure times of 2-6 h.

\section{EXPERIMENTAL METHOD}

\section{Boriding and characterization}

The chemical composition of the 34CrNiMo6 steel was $0.34 \mathrm{wt} \% \mathrm{C}, 0.40$ (max) wt\% $\mathrm{Si}$, $0.65 \mathrm{wt} \% \mathrm{Mn}, 1.50 \mathrm{wt} \% \mathrm{Cr}, 0.23 \mathrm{wt} \% \mathrm{Mo}$ and $1.50 \mathrm{wt} \% \mathrm{Ni}$. The samples were cut to dimensions of $10 \mathrm{~mm} \times 10 \mathrm{~mm} \times 50 \mathrm{~mm}$ from a 10 - $\mathrm{mm}$ thick plate. The samples were packed in commercial Ekabor-II boron source and ferro-silicon as an activator. The samples were borided in a muffle furnace at temperatures of 1123,1173 and $1223 \mathrm{~K}$ for durations of 2, 4 and $6 \mathrm{~h}$. After boriding, the samples were removed from the furnace and cooled in air. Crosssectional samples were then prepared and cold-mounted in epoxy resin, ground with 180, 320, 600 and 1000 grit $\mathrm{SiC}$ papers, and polished using $6 \mu \mathrm{m}$ diamond paste for studying microstructures and microhardness. The polished samples were then dried up and metallographically etched with a $4 \%$ Nital solution.

The phases formed on the surface of the borided 34CrNiMo6 steels were determined using a Rigaku D-MAX 2200 X-ray diffractometer with $\mathrm{CuK} \alpha$ radiation of $0.15418 \mathrm{~nm}$ wavelength. Metallographic cross-sections were prepared and the morphological details and microstructures of the boride layer were examined by optical microscopy. High magnification imaging was carried out using a JEOL 5600LV scanning electron microscope. 


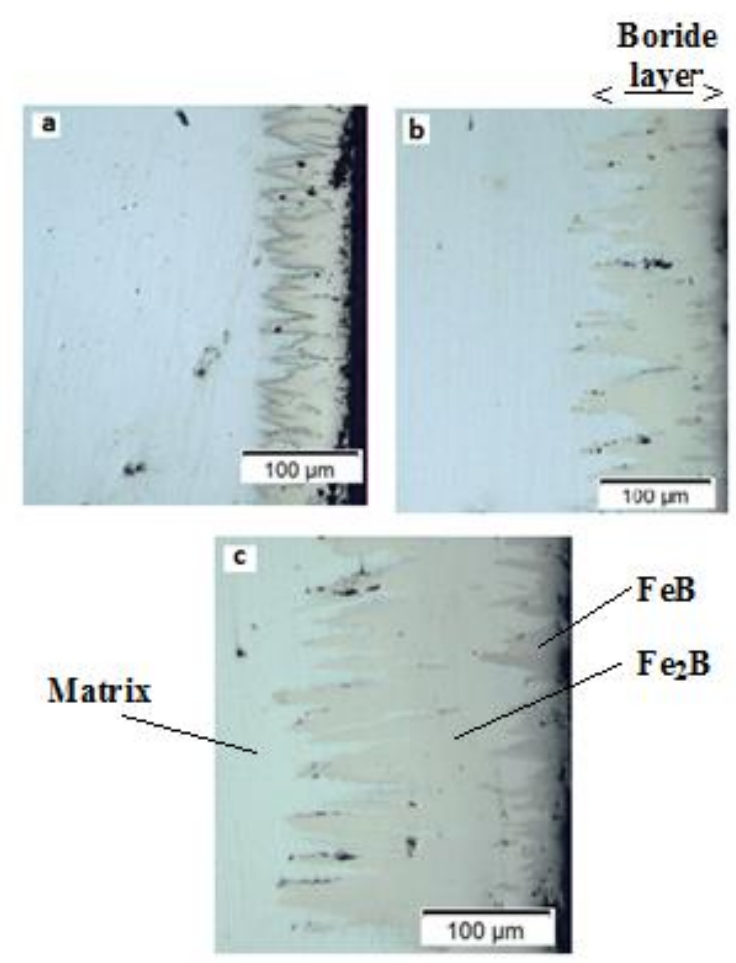

Fig. 1. Optical micrographs in the cross-section of the specimen borided at $1223 \mathrm{~K}$ for 2 (a), 4 (b) and $6 \mathrm{~h}$ (c)

To construct the hardness profiles of the borided 34CrNiMo6 steels, a Vickers microhardness tester with an indentation load of $100 \mathrm{~g}$ and dwell time of $10 \mathrm{~s}$ was used. Many indentations were made on surfaces of borided steels under each experimental condition to check the reproducibility of hardness data. Boride layer thicknesses were measured by the method provided by Yu et al. [25].

\section{RESULTS AND DISCUSSION}

\section{Microstructures of the borided specimens}

Optical micrographs of the cross-sections of 34CrNiMo6 steel borided at $1223 \mathrm{~K}$ for 2,4 and $6 \mathrm{~h}$ are given in Fig. 1. The boride layers formed on the surface of the borided steel have a sawtooth morphology. As boriding is a thermochemical diffusional process, the thickness of the boride layers and the diffusion zone increase with boriding time.

The average boride layer thicknesses of borided 34CrNiMo6 steels ranged from $22 \pm 2.3$ to $145 \pm 4.1 \mu \mathrm{m}$ depending on boriding time and temperature (Fig. 2). The obtained values show similarities with results obtained for other medium carbon steels reported in the literature [20,21,26,27]. Corresponding to this, Sen et al. [26] and Altinsoy et al. [27] showed that boride layer thickness of medium carbon steels (AISI 4340 and AISI 1020) changed from 21 to $238 \mu \mathrm{m}$ and from 20.5 to $216 \mu \mathrm{m}$ between 1073 and $1273 \mathrm{~K}$ for durations of $2,4,6$ and $8 \mathrm{~h}$, respectively. 


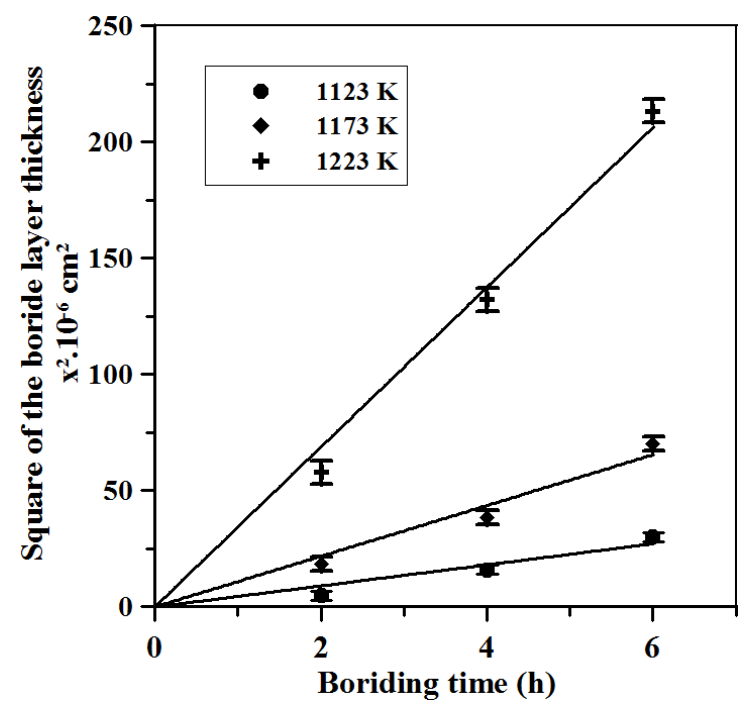

Fig. 2. Square of the boride layer thickness of borided 34CrNiMo6 steel as a function of boriding time and temperature

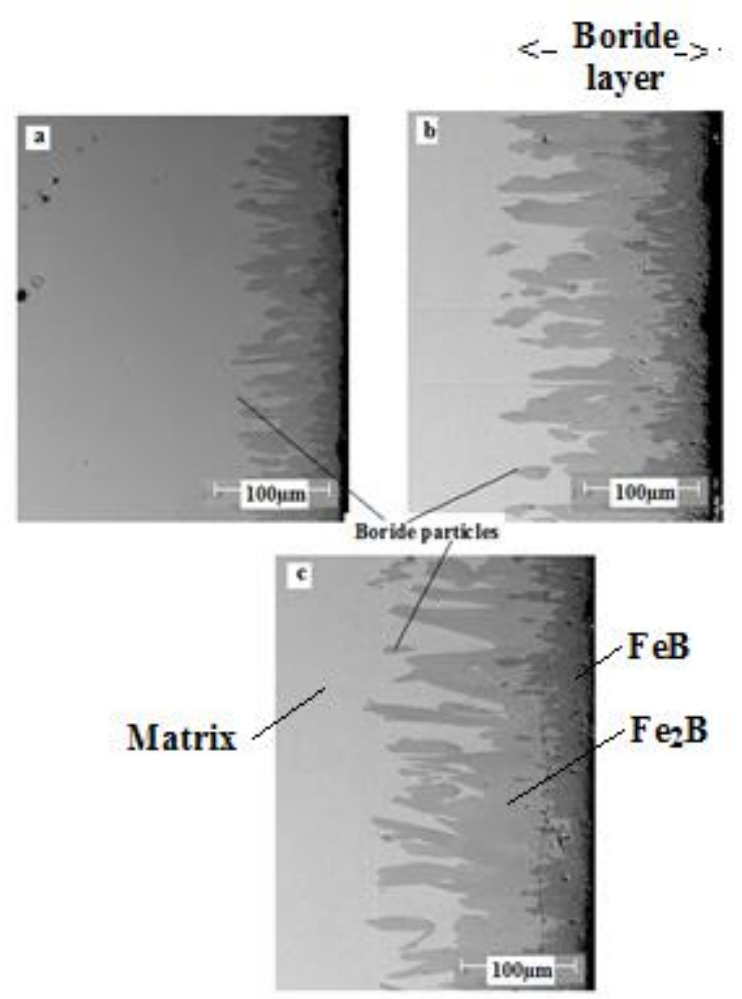

Fig. 3. SEM micrographs of $34 \mathrm{CrNiMo} 6$ steel borided at $1123 \mathrm{~K}(\mathrm{a}), 1173 \mathrm{~K}(\mathrm{~b})$ and $1223 \mathrm{~K}(\mathrm{c})$ for $6 \mathrm{~h}$

Cross-sectional SEM images of the 34CrNiMo6 steel borided at the temperatures of 1123,1173 and $1223 \mathrm{~K}$ for $6 \mathrm{~h}$ are shown in Fig. 3. In this figure, two distinct regions are identified on cross-sections of the borided specimens: (i) the boride layer and (ii) the substrate essentially unaffected by boron diffusion. Characteristic $\mathrm{FeB}$ (outer) and $\mathrm{Fe}_{2} \mathrm{~B}$ phases (inner) in the boride layer are distinguishable. Furthermore, small $\mathrm{Fe}_{2} \mathrm{~B}$ boride particles are also observed beneath and in between the $\mathrm{Fe}_{2} \mathrm{~B}$ needles adjacent to the matrix. 


\section{$X$-Ray diffraction analysis}

Diffraction patterns of 34CrNiMo6 borided at $1123 \mathrm{~K}$ and $1223 \mathrm{~K}$ for $6 \mathrm{~h}$ are presented in Fig. 4. At $1123 \mathrm{~K}$, XRD patterns reveal that $\mathrm{FeB}$ and $\mathrm{Fe}_{2} \mathrm{~B}$ phases are the dominant phases in the boride layer (Fig. 4a). The diffraction patterns also show peaks belonging to chromium iron carbide $(\mathrm{Cr}, \mathrm{Fe})_{23} \mathrm{C}_{6}\left(\mathrm{Cr}_{15.58} \mathrm{Fe}_{7.42} \mathrm{C}_{6}\right)$. This phase was also identified by Yamazagi et al. [28] and Ohta et al. [29]. When the boriding temperature is increased to $1223 \mathrm{~K}, \mathrm{Fe}_{3} \mathrm{O}_{4}$ (magnetite) is detected in addition to the $\mathrm{FeB}$ and $\mathrm{Fe}_{2} \mathrm{~B}$ phases. This observation confirms that the surface of borided samples have been oxidized because of non protective atmosphere of the boriding medium as indicated in Reference [30].
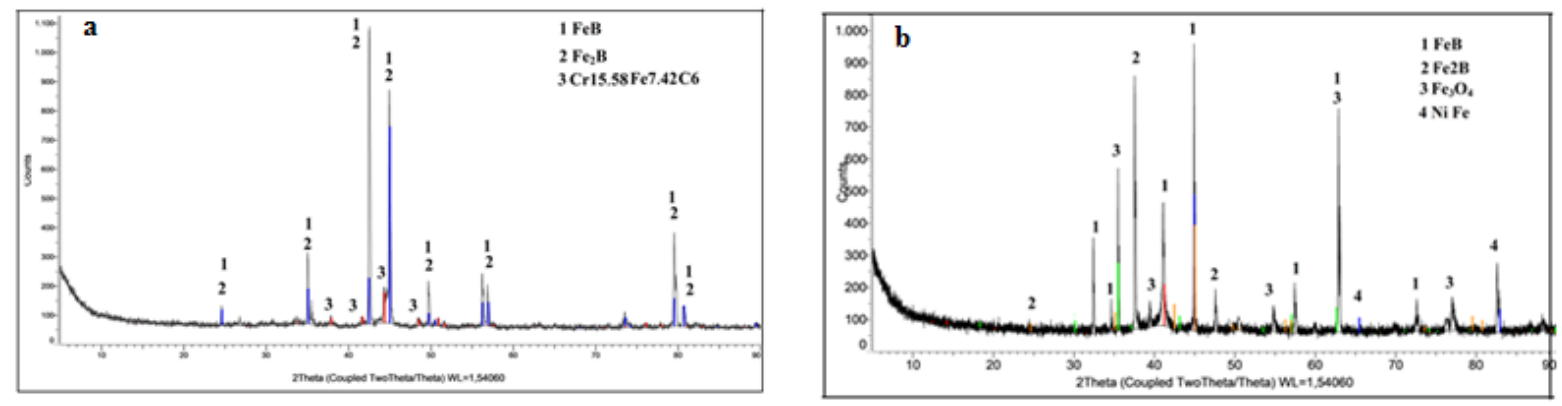

Fig. 4. XRD patterns of borided 34CrNiMo6 at $1123 \mathrm{~K}$ (a) and $1223 \mathrm{~K}$ (b) for $6 \mathrm{~h}$

In the literature, it has been reported that the alloying elements can lead to the formation of mixed borides in the boride layer of alloy steels [4]. Corresponding to this, Azakli et al. [31] noted that $\mathrm{Mo}_{2} \mathrm{FeB}_{2}$ precipitates were formed in the boride layer and transition zone of borided $\mathrm{Fe}-\mathrm{Mo}$ binary alloys. In the present study, complex borides were not observed, but Ni-Fe was observed at $1223 \mathrm{~K}$ (Fig. 4b).

\section{Hardness tests}

Vickers microhardness tests were carried out across the cross-sections of the borided specimens to obtain the hardness profiles (Fig. 5).

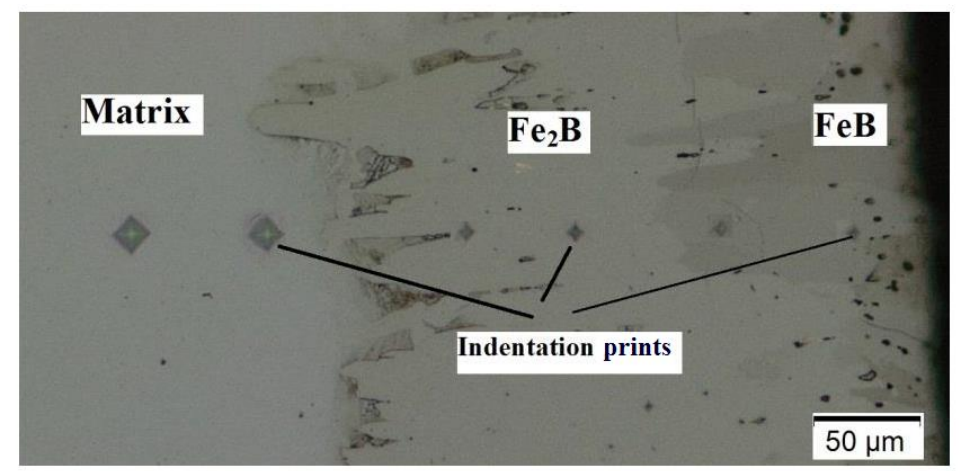

Fig. 5. Optical images of the indentation prints on the $34 \mathrm{CrNiMo} 6$ steel borided at $1223 \mathrm{~K}$ for $6 \mathrm{~h}$

Fig. 6 shows the microhardness profiles of borided 34CrNiMo6 steel as a function of boriding temperature and time. It can be seen from the figure that the boriding process significantly increases the hardness of the boride layer compared to the matrix. There is more than a 7-fold increase in hardness at the surface. This is a consequence of the presence of hard 
boride phases ( $\mathrm{FeB}, \mathrm{Fe}_{2} \mathrm{~B}$, and additionally from $\mathrm{Ni}-\mathrm{Fe}$ due to solid solution hardening) as determined by the XRD analysis in this region. On the other hand, the decrease in the hardness value towards the matrix is explained by the increasing proportion of the matrix surrounding the iron boride needles $[23,32,33]$. In addition to this, the outer FeB phase in the boride layer was found to be much harder than the inner $\mathrm{Fe}_{2} \mathrm{~B}$ phase (Fig. 5 and 6) because the bonds in $\mathrm{FeB}$ were slightly stronger than those in $\mathrm{Fe}_{2} \mathrm{~B}$ [34]. The obtained hardness values are very close to the values obtained for medium carbon steels. For similar boriding conditions $(1123 \mathrm{~K}$ and $4 \mathrm{~h})$, the hardness values of the boride layer obtained are around 1600 $\mathrm{HV}_{0.1}, 1800 \mathrm{HV}_{0.1}$ and $1700 \mathrm{HV}_{0.1}$ for borided medium carbon steels $32 \mathrm{NiCrMo6.4}$ [4], SAE 1035 [32] and AISI 1040 [35], respectively.

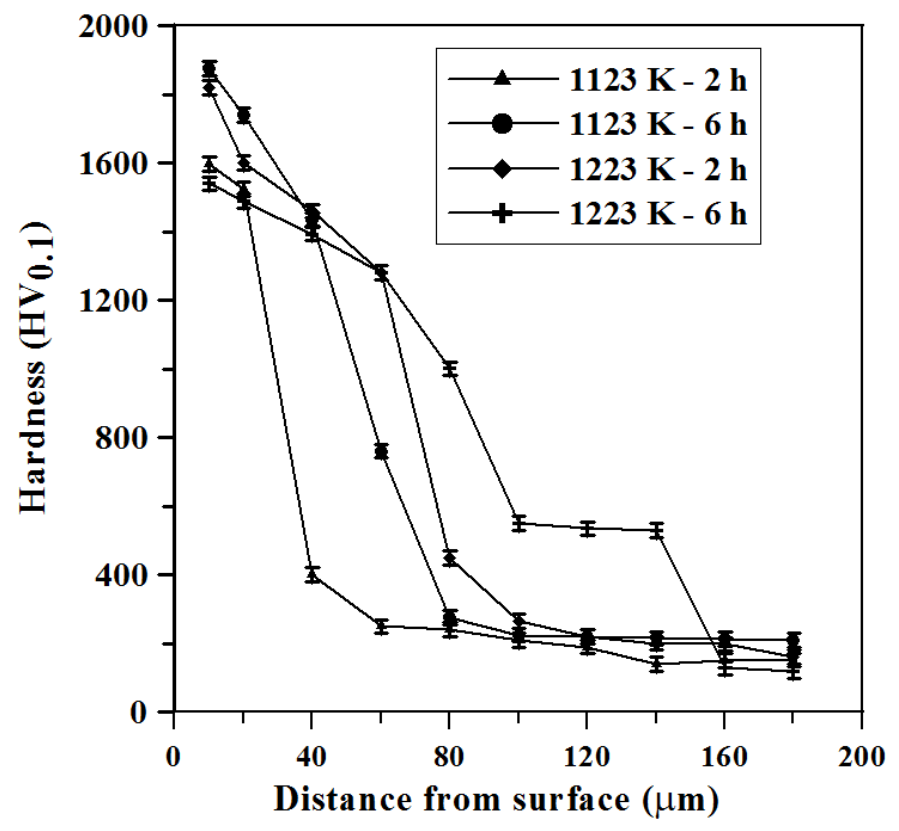

Fig. 6. Microhardness profiles of specimens borided at 1123 and $1223 \mathrm{~K}$ for 2 and $6 \mathrm{~h}$

\section{Boriding kinetics}

Boriding parameters such as processing temperature and time have to be known to predict the thickness of the boride layer which is formed by the diffusion of boron atoms into the substrate. In the literature [17,21,32,36], the relationship between square of boride layer thickness and boriding time obeys a parabolic growth law and is given as follows;

$$
d^{2}=K t
$$

where $d$ is the thickness of boride layer (m), $t$ is the boriding time (s), and $K$ is the growth rate constant for the boriding temperature $\left(\mathrm{m}^{2} / \mathrm{s}\right)$. Meanwhile, the relationship between growth rate and the boriding temperature can be described by an Arrhenius equation of the form $[7,10,13,14,35]$ :

$$
K=K_{0} \exp \left(-\frac{\mathrm{Q}}{R T}\right)
$$

where $K_{0}$ is the collision factor $\left(\mathrm{m}^{2} / \mathrm{s}\right), Q$ is the activation energy for the particular reaction $(\mathrm{J} / \mathrm{mol}), T$ is the absolute temperature $(\mathrm{K})$ and $R$ is the universal gas constant $(\mathrm{J} /(\mathrm{mol} \cdot \mathrm{K}))$. 


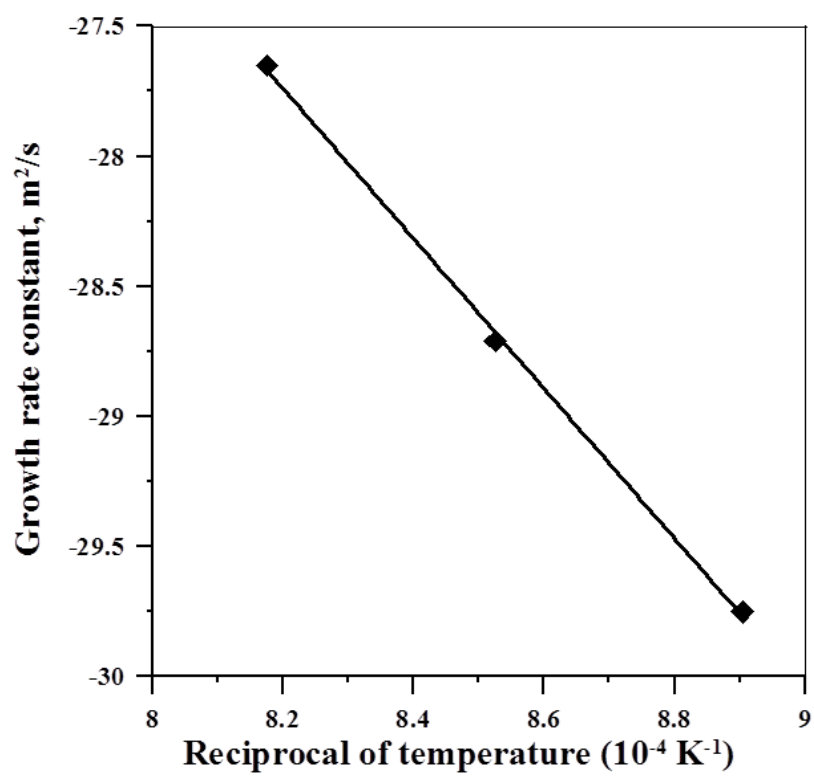

Fig. 7. Growth rate constant of $34 \mathrm{CrNiMo6}$ steel borided with Ekabor II powders as a function of reciprocal of temperature

The effect of the boriding temperature and time on the growth kinetics of the boride layer was also investigated. The growth rate constants were calculated using Eq. 1 for the three boriding temperatures. The change in $K$ with $T$ is plotted in Fig. 2 and also listed in Table 1 . The growth rate constant $K$ determines the rate at which borides grow on the surface of the steel, and Table 1 shows that higher process temperatures result in higher $K$ values. When $\ln K$ is plotted with respect to the reciprocal of absolute temperature (Fig. 7), the activation energy $Q$ and collision factor $K_{0}$ can be calculated from the slope and y-intercept, respectively (Eq. 2).

The calculated Q and $K_{0}$ values are given in the Table 1. A direct comparison of $K$ and $Q$ values for 34CrNiMo6 steel could not be made, since no boriding studies on 34CrNiMo6 steel could be found. Comparisons were therefore made using results from other borided medium carbon steels. However, it can be seen from Table 2 that the $Q$ values of medium carbon steels also depend on the type of boriding process. Table 2 clearly shows that the $Q$ values obtained through plasma paste boriding method were established to be quite low compared to those obtained through traditional boriding methods. The high rate of boriding by the plasma paste method has been explained by the extensive amounts of active boron generated by the plasma, which does not exist in the pack boriding method [37]. Campos et al. [38] have shown that the boron potential can be controlled by modifying the thickness of the paste and by changing water/powder ratio in the paste.

Table 1. Calculated growth rate constants and activation energy for the $34 \mathrm{CrNiMo6}$ steels

\begin{tabular}{cccc}
\hline $\begin{array}{c}\text { Temperature } \\
\mathrm{T}(\mathrm{K})\end{array}$ & $\begin{array}{c}\text { Growth rate constant } \\
\mathrm{K}\left(\mathrm{m}^{2} / \mathrm{s}\right)\end{array}$ & $\begin{array}{c}\text { Activation energy } \\
\mathrm{Q}(\mathrm{kJ} / \mathrm{mol})\end{array}$ & $\begin{array}{c}\text { Collision factor } \\
\mathrm{K}_{0}\left(\mathrm{~m}^{2} / \mathrm{s}\right)\end{array}$ \\
\hline 1123 & $0.12 \times 10^{-12}$ & & \\
1173 & $0.34 \times 10^{-12}$ & $239.4 \pm 8.6$ & $1.65 \times 10^{-2}$ \\
1223 & $0.98 \times 10^{-12}$ & & \\
\hline
\end{tabular}

The activation energy value obtained in our study is $239.4 \pm 8.6 \mathrm{~kJ} / \mathrm{mol}$ which differs slightly from the activation energy values obtained for other medium carbon steels for the 
same boriding temperature in Ekabor II. The difference is probably due to the chemical composition of the substrate. Regarding the alloy element concentrations in the four medium carbon steels borided with Ekabor II in Table 2, there are differences in $\mathrm{Cr}, \mathrm{Ni}, \mathrm{Mo}$ and $\mathrm{Mn}$ content between each. While $\mathrm{C}, \mathrm{Mo}$ and $\mathrm{W}$ in the alloy dramatically reduce the rate of the boriding process, $\mathrm{Si}, \mathrm{Cr}$ and $\mathrm{Al}$ have moderate influence [38-41]. Similar discussions have been given in Ref. 42. In that study, it has been noted that activation energy values change with the chemical composition of the steel because alloying elements can often act as a barrier for boron diffusion. It has also been shown $[4,16,42,43]$, that the activation energy also depends on the methods used for measuring the thickness of the boride layer, surface preparation, the type and size of the boriding powders, and whether a single-phase ( $\mathrm{FeB})$ or double-phase boride layer $\left(\mathrm{FeB}+\mathrm{Fe}_{2} \mathrm{~B}\right)$ is formed (due to boron potential).

Table 2. The comparison of the activation energies obtained for medium carbon steels exposed to boriding

\begin{tabular}{ccccc}
\hline Steels & $\begin{array}{c}\text { Temperature } \\
\text { range }(\mathrm{K})\end{array}$ & Q $(\mathrm{kJ} / \mathrm{mol})$ & Boriding process & Reference \\
\hline AISI 4340 & $1073-1223$ & 234 & Salt bath & Sen et al. [26] \\
32NiCrMo6.4 & $1123-1223$ & 294.3 & Ekabor II powders & Gunes [41] \\
AISI P20 & $1123-1223$ & 256.4 & Ekabor II powders & Kayali [7] \\
& & 213.9 & Microwave & \\
34CrAlNi7 & $1123-1223$ & 270 & Ekabor II powders & Efe et al. [20] \\
34CrAlNi7 & $1123-1323$ & 169 & Ekabor I & Topuz et al. [21] \\
AISI P20 & $1073-1223$ & 200 & Ekabor II powders & Uslu et.al [8] \\
AISI 1035 & $1073-1273$ & 227.5 & Salt bath & Kaouka et al. [32] \\
AISI 1038 & $1123-1273$ & 207.8 & Liquid & Mebarek et. al. [44] \\
AISI 1045 & $1193-1273$ & 179 & Paste & Campos et.al. [38] \\
AISI 8620 & $973-1073$ & $124.7-138.5$ & Plasma paste & Gunes et.al. [45] \\
34CrNiMo6 & $1123-1223$ & $239.4 \pm 8.6$ & Ekabor II powders & Present study \\
\hline
\end{tabular}

The collision factor $K_{0}$ is constant and is a measure of the effective collisions between reacting species. From the calculated values of $Q$ and $K_{0}$, an empirical equation was developed for predicting the boride layer thickness by the classical kinetic diffusion theory for $34 \mathrm{CrNiMo6}$ steel for given the time and temperature.

$$
d=12.84 x 10^{-2} \sqrt{t \exp \left(-\frac{28794.8}{T}\right)} \quad 1123 \mathrm{~K}<\mathrm{T}<1223 \mathrm{~K}
$$

The correlation coefficient between the predicted and experimental boride layer thickness values for borided 34CrNiMo6 steel was found to be 0.912 .

\section{CONCLUSIONS}

Boriding of 34CrNiMo6 steel was successfully carried out using the pack boriding technique. The following points can be concluded from the present study:

- The dominant phases formed on the surface of 34CrNiMo6 steel after boriding are $\mathrm{FeB}$ and $\mathrm{Fe}_{2} \mathrm{~B}$.

- The boride layer thickness ranged between $22 \pm 2.3$ to $145 \pm 4.1 \mu \mathrm{m}$ depending on temperature and time. 
- After boriding, a significant improvement in surface hardness was observed. The microhardness of boride layer was about $1857 \mathrm{HV}_{0.1}$ for $6 \mathrm{~h}$ at $1223 \mathrm{~K}$, while that of unborided steel substrate was about 238 HV0.1

- The activation energy for boron diffusion value was found to be $239.4 \pm 8.6 \mathrm{~kJ} \mathrm{~mol}^{-1}$, which is close to the values expected for medium carbon steels.

\section{ACKNOWLEDGMENTS}

This study was supported by the Suleyman Demirel University Scientific Research Fund, project number FYL-2019-7320.

\section{REFERENCES}

1. Gong, B., Duan, X.W., Liu, J.S., Liu.J.J., A physically based constitutive model of As-forged 34CrNiMo6 steel andprocessing maps for hot working. Vacuum, 155 (2018) 345-357.

2. Branco, R., Costa, J.D., Antunes. F.V., Low-cycle fatigue behaviour of 34CrNiMo6 high strength steel. Theoretical and Applied Fracture Mechanics, 58 (2012) 28-34.

3. Wu, Z., Huang, C., Liu, F., Xia, C., Ke, L., Microstructure and Mechanical Properties of 34CrNiMo6 Steel Repaired by Friction Stir Processing Materials, 12 (2019) 1-11.

4. Litoria, A.K., Figueroa, C.A., Bim, L.T., Pruncu, C.I., Joshi, A.A., Hosmani. S.S., Packboriding of low alloy steel: microstructure evolution and migration behaviour of alloying elements. Philosophical Magazine, 100 (2020) 353-378.

5. Yorulmaz, M.A., An investigation of boriding of medium carbon steels, MSc, Marmara University, Istanbul, Turkey, 2007.

6. Bejar, M.A., Moreno, E., Abrasive wear resistance of boronized carbon and low-alloy steels. Journal of Materials Processing Technology, 173 (2006) 352-358.

7. Kayali, Y., Investigation of Diffusion Kinetics of Borided AISI P20 Steel in Micro-Wave Furnace. Vacuum, 121 (2015) 129-134.

8. Uslu, I., Comert, H., Ipek, M., Ozdemir, O., Bindal, C., Evaluation of borides formed on AISI P20 steel. Materials and Design, 28 (2007) 55-61.

9. Yusuf, K.M., Abdullah, B., Saad, N.H., Proceedings of Asia International Conference on Tribology, (2018) 424-426.

10. Rodríguez-Castro, R., Campos-Silva,I., Martínez-Trinidad, J., Figueroa-López, U., ArzateVázquez, I., Hernández-Sánchez, E., Hernández-Sánchez, J., Mechanical behavior of AISI 1045 steels subjected to powder-pack boriding, Kovove Mater, 50 (2012) 357-364.

11. Culha, O., Toparli, M., Sahin, S., Aksoy. T., Characterization and determination of FexB layers' mechanical properties. Journal of Materials Processing Technology, 206 (2008) 231-240.

12. Ucisik, A.H., Zeytin, S., Bindal, C., Boride coating on iron based alloys. Journal of the Australian Ceramic Society, 37 (2001) 83-94.

13. Gunes, I., Keddam, M., Chegroune, E., Ozcatal. M., Growth kinetics of boride layers formed on 99.0\% purity nickel. Bulletin of Materials Science, 38 (2015) 1113-1118.

14. Dybkov, V.I., Goncharuk, L.V., G. Khoruzha, V.G., Meleshevich, K.A., Samelyuk, A.V., Sidorko. V.R., Diffusional Growth Kinetics of Boride Layers on Iron-Chromium Alloys. Solid State Phenomena, 138 (2008) 181-188. 
15. Kulka, M., Makuch, N., Pertek, A., Maldzinski, L., Simulation on growth kinetics of boride layers formed on $\mathrm{Fe}$ during gas boriding in $\mathrm{H} 2-\mathrm{BCl} 3$ atmosphere. Journal of Solid State Chemistry, 199 (2013) 196-203.

16. Ortiz-Domínguez, M.O., Gómez-Vargas, A., Ares de Parga, G., Torres-Santiago, G., VelázquezMancilla, R., Castellanos-Escamilla, V.A., Mendoza-Camargo, J., Trujillo-Sánchez, R., Modeling of the Growth Kinetics of Boride Layers in Powder-Pack Borided ASTM A36 Steel Based on Two Different Approaches. Advances in Materials Science and Engineering, 2019 (2019) 1-12.

17. Zuno-Silva, J., Ortiz-Domínguez, M., Keddam, M., Elias-Espinosa, M., Damián-Mejía, O., Cardoso-Legorreta, E., Abreu-Quijano, M., Boriding kinetics of Fe2B layers formed on AISI 1045 steel. Journal of Mining and Metallurgy, , Section B: Metallurgy, 50 (2014) 101-107.

18. Keddam, M., Kulka, M.,Simulation of the Growth Kinetics of FeB and Fe2B Layers on AISI D2 Steel by the Integral Method., Physics of Metals and Metallography, 119, (2018) 842-851.

19. Zuno-Silva, J., Keddam, M., Ortiz-Domínguez, M., Elias-Espinosac, M.C., Cervantes-Sodid, F., Oseguera-Peña, J., De-Diosf, L.D.F., Gomez-Vargasf, O.A., Materials Research, 21 (2018) 1-10.

20. Efe, G.C. Mediha, I., Ozbek, I., Bindal, C., Kinetics of borided 31CrMoV9 and 34CrAlNi7 steels. Materials Characterization, 59 (2008) 23-31.

21. Topuz, P., Aydogmus, T., Aydin, O., Kinetic Investigation of Boronized 34CrAlNi7 Nitriding Steel. International Journal of Engineering and Natural Sciences, 2 (2019) 17-22.

22. Sahin, S., Effects of boronizing process on the surface roughness and dimensions of AISI 1020, AISI 1040 and AISI 2714. Journal of Materials Processing Technology, 209 (2009) 1736-1741.

23. Joshi, A.A., Hosmani. S.S., Pack-Boronizing of AISI 4140 Steel: Boronizing Mechanism and the Role of Container Design. Journal of Materials and Manufacturing Processes, 29 (2014) 10621072.

24. Nora, R.T., Zine, T.M., Abdelkader, K., Youcef, K., Ali, O., Jiang, X., Revista Matéria, Vol. 24, 2019, pp. 1-11.

25. Yu, L.G., Chen, X.J., Khor, K.A., Sundararajan, G., FeB/Fe2B phase transformation during SPS pack-boriding: Boride layer growth kinetics. Acta Materialia, 53 (2005) 2361-2368.

26. Sen, S., Sen, U., Bindal, C., An Approachto Kinetic Study of Borided Steels. Surface Coating Technology, 191(2005) 274-285.

27. Altinsoy, I., Efe, F.G. Celebi., Ipek, M., Ozbek, I., Zeytin, S., Bindal, C., An investigation on borided AISI 1020 steel. International Advanced in Applied Physics and Materials Sciences, 1569 (2013)43-48.

28. Yamazaki, Y., Sugihara, M., Takaki, S., Abiko, K., Iijima, Y., Volume and Grain-Boundary SelfDiffusion in a High-Purity Fe50 mass\% Cr Alloy Physica Status Solidi (a), 189 (2002) 97-105.

29. Ohta, J., Kako, K., Mayuzumi, M., Kusanagi, H., Abiko. K., In situ Transmission Electron Microscopy of Carbide Precipitation in Fe-50\%Cr Alloys at Elevated Temperatures. Materials Transactions, 41 (2000) 130-135.

30. Rao, D., Upadhyaya, G.S., Sintering of Mo2FeB2 layered cermet containing SiC fibers. Materials Chemistry and Physics, 70 (2001) 336-339.

31. Azakli, Y., Cengiz, S., Tarakci, M., Gencer, Y., Characterisation of boride layer formed on $\mathrm{Fe}-$ Mo binary alloys. Surface Engineering , 32 (2016) 589-595.

32. Kaouka, A., Allaoui, O., Keddam, M., Growth kinetics of the boride layers formed on SAE 1035 steel. Mat'eriaux and Techniques, 101 (2013)705-712. 
33. Keddam, M., Chegroune, R., Kulka, M., Makuch, N., Panfil, D., Siwak, P., Taktak, S., Characterization, tribological and mechanical properties of plasma paste borided AISI 316 steel. Transactions of the Indian Institute of Metals, 71 (2018) 79-90.

34. Kunitskii, Y.A., Marek, E.V., Some physical properties of iron borides. Soviet Powder Metallurgy and Metal Ceramics, 10 (1971) 216-218.

35. Calik, A., Taylan, F., Sahin, O., Ucar, N., Comparison of mechanical properties of boronized and vanadium carbide coated AISI 1040 steels. Indian Journal of Engineering and Materials Sciences, 16 (2009) 326-330.

36. Karakas, M.S., Gunen, A., Kanca, E., Yilmaz, E., Boride Layer Growth Kinetics of AISI H13 Steel Borided with Nano-Sized Powders. Archives of Metallurgy and Materials, 63 (2018)159165

37. Yoon, J.H., Jee, Y.K., Lee, S.Y., Plasma paste boronizing treatment of the stainless steel AISI 304, Surface and Coatings Technology 112 (1999 ) 71-75

38. Campos, I., Ramirez, G., Figueroa, U., Martinez, J., Morales, O., Evaluation of boron mobility on the phases FeB, Fe2B, and diffusion zone in AISI 1045 and M2 steels, Applied Surface Sciences, 253 (2007) 3469-3475.

39. Pertek, A., Kulka, M., Characterization of complex (BpC) diffusion layers formedon chromium and nickel-based low-carbon steel. Applied Surface Science, 202 (2002) 252-260.

40. Carbucicchio, M., Palombarini, G., Effects of alloying elements on the growth of iron boride coatings, Journal of Materials Science Letters, 6 (1987)1147-1149.

41. Gunes, I., Kinetics of borided gear steels. Sadhana, Vol. 38, No. 3, 2013, pp. 527-541.

42. Jain, V., Sundararajan, G., Influence of the Pack Thickness of the Boronizing Mixture on the Boriding of Steel. Surface Coating Technology, 149 (2002) 21-26.

43. Brakman, C.M., Gommers, A.W.J., Mittemeijer, E.J., Boriding of $\mathrm{Fe}$ and $\mathrm{Fe}-\mathrm{C}, \mathrm{Fe}-\mathrm{Cr}$, and $\mathrm{Fe}-$ Ni alloys; Boride-layer growth kinetics. Journal of Materials Research, 4 (1989) 1354-1370.

44. Mebarek, B., Benguelloula, A., Zanoun, A., Effect of Boride Incubation Time During the Formation of Fe2B Phase, Mat. Res. 21 (2017) 1-6

45. Gunes, I., Taktak, S., Bindal, C., Yalcin, Y., Ulker, S., Kayali, Y., Investigation of diffusion kinetics of plasma paste borided AISI 8620 steel using a mixture of $\mathrm{B} 2 \mathrm{O} 3$ paste and $\mathrm{B} 4 \mathrm{C} / \mathrm{SiC}$, Sadhana, 38 (2013) 513-526. 